\title{
Chapter 14 \\ Assisted Reproductive Technology in Europe: \\ Usage and Regulation in the Context \\ of Cross-Border Reproductive Care
}

\author{
Patrick Präg and Melinda C. Mills
}

\subsection{Introduction}

Involuntary childlessness, or infertility, is a condition that affects a sizeable number of couples around the world (Mascarenhas et al. 2012). Assisted reproductive technologies (ART) represent an important set of techniques for addressing involuntary childlessness. While it has always been difficult to make a precise distinction between voluntary and involuntary childlessness, the main reasons for childlessness, such as the perceived lack of a suitable partner or problems associated with balancing work and family, can be seen as both voluntary and involuntary (Sobotka 2010). The current trend of fertility postponement in European societies (Mills et al. 2011) has exacerbated the issue of involuntary childlessness. While it is clear that female fecundity declines sharply at higher ages, because the pace of fecundity loss varies greatly between women, it can be difficult for an individual woman to ascertain how long she can postpone childbearing (te Velde and Pearson 2002; te Velde et al. 2012).

ART is increasingly perceived as being one way to alleviate the problems of involuntary childlessness. Between the birth in 1978 of Louise Brown, the first live ART baby (Steptoe and Edwards 1978), and the awarding of the Nobel Prize in Physiology or Medicine to Robert G. Edwards for the development of in vitro fertilization in 2010, ART had become a standard medical practice and a profitable commercial enterprise for thousands of firms in Europe. An estimated five million babies have been born with the help of assisted reproduction in the past four decades (Adamson et al. 2013), a sizable share of them in Europe.

ART generally refers to treatments in which gametes or embryos are handled in vitro ("in glass;" i.e., outside of the body) to establish a pregnancy. A key technique

P. Präg $(\bowtie) \bullet$ M.C. Mills

Department of Sociology and Nuffield College, University of Oxford, Oxford, UK

e-mail: patrick.prag@ sociology.ox.ac.uk; melinda.mills@ sociology.ox.ac.uk 
of ART is in vitro fertilization (IVF). In IVF, oocytes are fertilized using sperm in a laboratory and the embryo is surgically implanted in the woman's womb. IVF was invented to treat cases of female infertility. When only a single sperm cell is injected into the oocyte during IVF, the procedure is referred to as intracytoplasmic sperm injection (ICSI). ICSI was developed to tackle male fertility problems, such as a low sperm count or poor sperm quality, but has in recent years become a standard form of fertilization in ART. A frozen or thawed embryo transfer is an IVF procedure in which embryos that have been cryopreserved for storage are transferred (as opposed to a "fresh" transfer of never-frozen embryos). This procedure is often used because obtaining oocytes from a woman is a rather invasive act. Thus, after a hormonal treatment, several oocytes are collected at the same time, fertilized, and frozen for later use in case the first embryo transfer fails-which is likely, given the relatively low success rate of ART (Malizia et al. 2009). In an alternative collection strategy, immature eggs are collected from a woman and are then matured in a lab (in vitro maturation). This procedure may be indicated when a woman is at risk of reacting adversely to the fertility drugs given before the oocytes are collected.

Frozen oocyte replacement is a technique in which oocytes are retrieved, frozen, stored (oocyte cryopreservation), and fertilized only after they have been thawed for transfer. This technique provides women with the option of having genetically related children later in life, even if no suitable father is present at the time of cryopreservation. Frozen oocyte replacement was first used in cancer patients, who had oocytes retrieved and frozen before undergoing forms of chemo- or radiotherapy that could damage their ovaries. But because this technique can also be used for delaying motherhood for any reason, including the desire to pursue a career, it has attracted substantial public attention in recent years, and is sometimes referred to as "social freezing" (Mertes and Pennings 2011). Large companies, such as Facebook and Apple, have recently offered social freezing as a benefit for female employees, offering them up to $\$ 20,000$ to cover the cost of egg freezing (Tran 2014).

When prospective parents are concerned about passing on hereditary diseases like cystic fibrosis, it can be useful to conduct preimplantation genetic diagnosis (PGD) or screening (PGS). PGD involves examining an embryo to determine whether specific genetic and structural alterations are present. In PGS, an embryo is examined to ascertain whether any aneuploidy, mutation, or DNA rearrangement has taken place. In cases of egg donation, an oocyte from a woman is fertilized and then transferred to another woman's womb. Donation may be done in cases of surrogate motherhood for prospective parents who are unable to carry a child, such as a gay male couple; or when a woman is unable to have her own oocytes fertilized, often because she is older. Another type of egg donation is called "egg sharing:" women who underwent ART can share any non-used frozen oocyte with other women, sometimes in exchange for a discount on their ART treatments.

Globally, Europe has the largest number of ART treatments. In 2005, the most recent year for which global data are available, $56 \%$ of ART aspirations ${ }^{1}$ were in

\footnotetext{
${ }^{1}$ Aspirations are initiated ART cycles in which one or more follicles are punctured and aspirated, irrespective of whether oocytes are retrieved. See Footnote 2 for more details on the metrics with which ART treatments are recorded.
} 
Europe, $23 \%$ were in Asia, and $15 \%$ were in North America (Zegers-Hochschild et al. 2014). As many European countries have been characterized as having "lowest-low" fertility (Kohler et al. 2002), ART represents not just a means of alleviating the suffering of individuals who are involuntarily childless, but also a potential policy lever for raising fertility rates in Europe. Thus, there is substantial interest in ART among policy-makers. Another key aspect of ART in Europe is the stark variation in the rates of ART uptake and in the regulation of ART, both across countries and over time. This variation in regulations between and within European countries allows us to make comparisons that could yield important insights into the antecedents and outcomes of ART usage and could have implications for ART across the globe.

The first aim of the current study is to present comparative data on ART usage in Europe, demonstrating the wide variability across European countries. In a second step, we will explore forms of ART governance across European countries, illustrating the variation in how ART is regulated and in who gets access to which techniques. We then turn to the specific case of surrogacy, which often falls outside the scope of national ART legislation. We conclude with a related discussion on crossborder reproductive care, which is sometimes characterized as "reproductive tourism." In the concluding section, we will summarize the findings, discuss the implications, and point to areas for future research.

\subsection{Usage of Assisted Reproductive Technologies in European Countries}

The usage of ART varies considerably across European countries. Although diagnostic and treatment services are currently available in all European countries, the variation in ART usage indicates that there are substantial differences in equity of access. To explore these differences, we analyze data collected by the European IVF Monitoring (EIM) Consortium of the European Society of Human Reproduction and Embryology (ESHRE). The EIM data go back to 1997, and are based on information from national registries (with the voluntary or mandatory participation) of European countries; or, if those are not available, stem from information reported by clinics. In our analysis, we primarily focus on information from the most recent report, which contains data for the year 2010 (Kupka et al. 2014), and present information from the countries that have complete or almost complete figures.

In Fig. 14.1, we can see the high degree of variation in ART usage across Europe. The figure shows the number of treatments ${ }^{2}$ by the main group of potential ART

\footnotetext{
${ }^{2}$ There are different metrics for recording ART treatments. The term "initiated ART cycle" refers to the menstrual cycle in which a woman receives ovarian stimulation (or, in the rare case of natural-cycle IVF, receives monitoring) with the intention of conducting ART, regardless of whether a follicular aspiration is attempted. The term "aspiration" refers to an attempt to retrieve oocytes from one or more follicles, regardless of whether oocytes are successfully retrieved. The term
} 


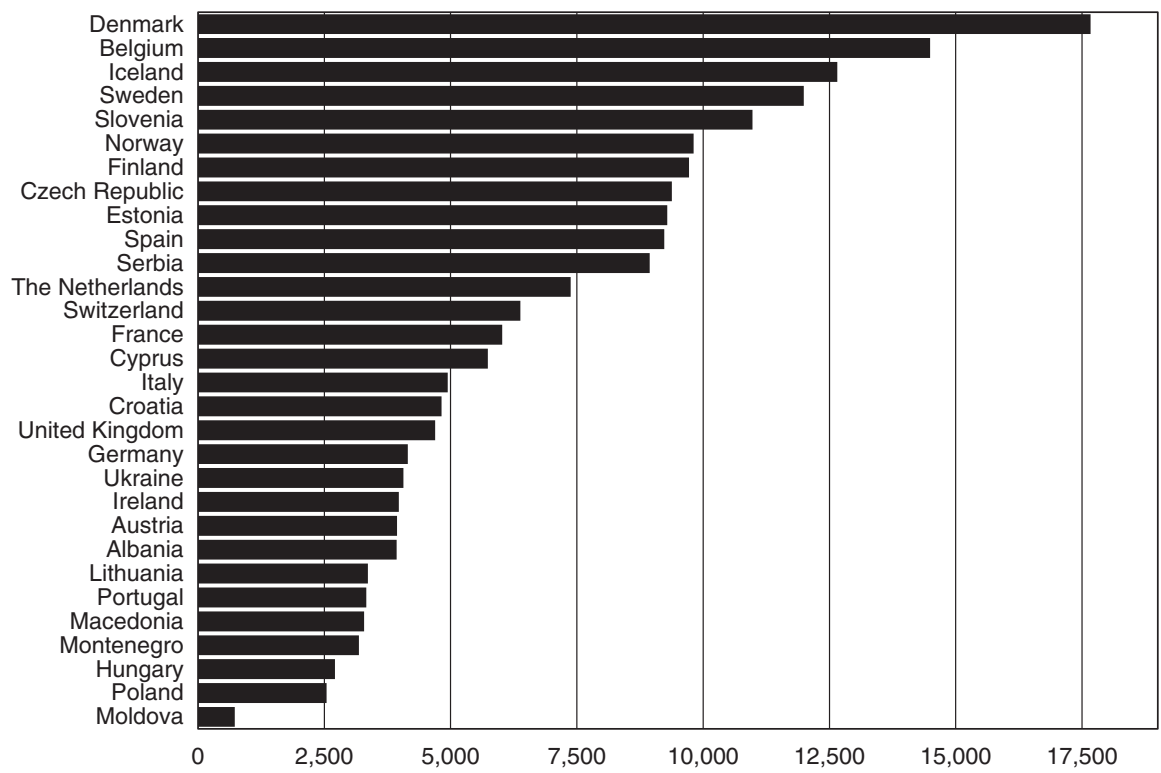

Fig. 14.1 ART cycles per million women age 15-45 per country, 2010 (Sources: Ferraretti et al. (2012, 2013) and Kupka et al. (2014). Notes: The values for Albania, Estonia, Ireland, Lithuania, Poland, Spain, Serbia, Switzerland, and Ukraine refer to 2008; the values for Croatia, Cyprus, and France, and Denmark refer to 2009. ART cycles include IVF, ICSI, frozen embryo replacement (thawings), preimplantation genetic diagnosis and screening, egg donation (donation cycles), in vitro maturation, and frozen oocyte replacement (thawings))

patients in a country; namely, women between the ages of 15 and 45. Denmark, Belgium, Iceland, Sweden, and Slovenia are the countries where the largest numbers of ART cycles are initiated. A comparison of these four countries shows that there is substantial heterogeneity at the top of the distribution. ART treatments are considerably more common in Belgium and Denmark than in Iceland, Sweden, and Slovenia. It is also striking that the top group is not completely dominated by affluent western European countries. In addition to Slovenia, the Czech Republic, Estonia, and Serbia are also in the upper half of the distribution; well ahead of wealthy nations such as Switzerland, the Netherlands, or Germany. When we look at the bottom of the distribution, it is apparent that ART is no more widespread in Germany, Austria, or Ireland than it is in Ukraine or in Albania.

A number of studies have attempted to explain the very large differences in ART usage across countries. Several factors have emerged. ART costs and affordability appear to play an important role. Belgium and Denmark are known for their comparatively generous reimbursement policies for couples and individuals under-

\footnotetext{
"transfer" refers to a procedure in which embryos are placed in the uterus or Fallopian tube, irrespective of whether a pregnancy is achieved (Zegers-Hochschild et al. 2009). However, for frozen embryo replacements, frozen oocyte replacements, and egg donations, cycles and aspirations are usually not recorded; here, thawings and transfers are the relevant metrics.
} 
going ART. In a cross-national study, Chambers et al. (2014) found that greater affordability of ART - measured as the net cost of an ART cycle in a country as a share of the average disposable income in that country-is associated with greater ART utilization. Remarkably, this finding holds even after accounting for important factors such as GDP per capita, the number of physicians, and the number of ART clinics in a country. Studies that have looked at variation within countries and over time (e.g., Hamilton and McManus 2012) have also found evidence that affordability is an important driver not only of utilization, but also of the use of safer ART practices.

Norms and beliefs also seem to play an important role for cross-national differences in ART usage. Billari et al. (2011) found that there is a large positive association between higher social age deadlines for childbearing-i.e., generally shared assumptions about when one is too old to have children - and the availability of ART in European countries. The higher the social age norm for childbearing, the greater the availability of ART clinics. Kocourkova et al. (2014) showed that ART use and the total fertility rate in a country are correlated, which they interpret as being a sign of increasing demand for children. This interpretation is plausible, as most studies have found that the net impact of ART on fertility rates is actually small (Präg et al. 2015). Mills and Präg (2015) have suggested that beliefs about the moral status of a fertilized egg-i.e., whether a human embryo is seen as a human being immediately after fertilization-are associated with ART utilization. Generally, in countries where the belief that an embryo becomes a human being right after fertilization is less widespread, ART is used more often.

In addition to the differences in the extent of ART usage in Europe, there is also considerable variation in the range of ART techniques that are utilized. Figure 14.2 reports the share of single ART treatments among all ART treatments for selected countries in 2010. The classical form of ART, in vitro fertilization, is no longer the most popular type of ART procedure. The share of IVF treatments among all ART treatments ranges from less than $10 \%$ in Spain to slightly more than $40 \%$ in Denmark. ICSI, a method invented more recently (Palermo et al. 1992) to treat male factor infertility, has overtaken IVF in recent years as the method of choice for ART (Kupka et al. 2014). The reasons for this development are not fully understood, especially because the leading professional organizations of reproductive health providers discourage the routine practice of ICSI in the absence of male factor infertility diagnoses (Boulet et al. 2015). It is likely related to what demographic researchers have called the "absent and problematic men" issue in fertility research and infertility diagnoses, as collecting data on men and establishing male factor infertility is difficult (Greene and Biddlecom 2000). Nonetheless, in virtually all of the countries displayed in Fig. 14.2, the share of ART procedures that are ICSI treatments is larger than the share of procedures that are IVF treatments. Only in Denmark is the share of ART procedures that are IVF treatments slightly larger (42\%) than the share that are ICSI treatments (35\%). In the United Kingdom, IVF and ICSI are used to a similar extent (37 and $40 \%$, respectively). The substantial differences between countries have been noted in the literature, yet explanations for 


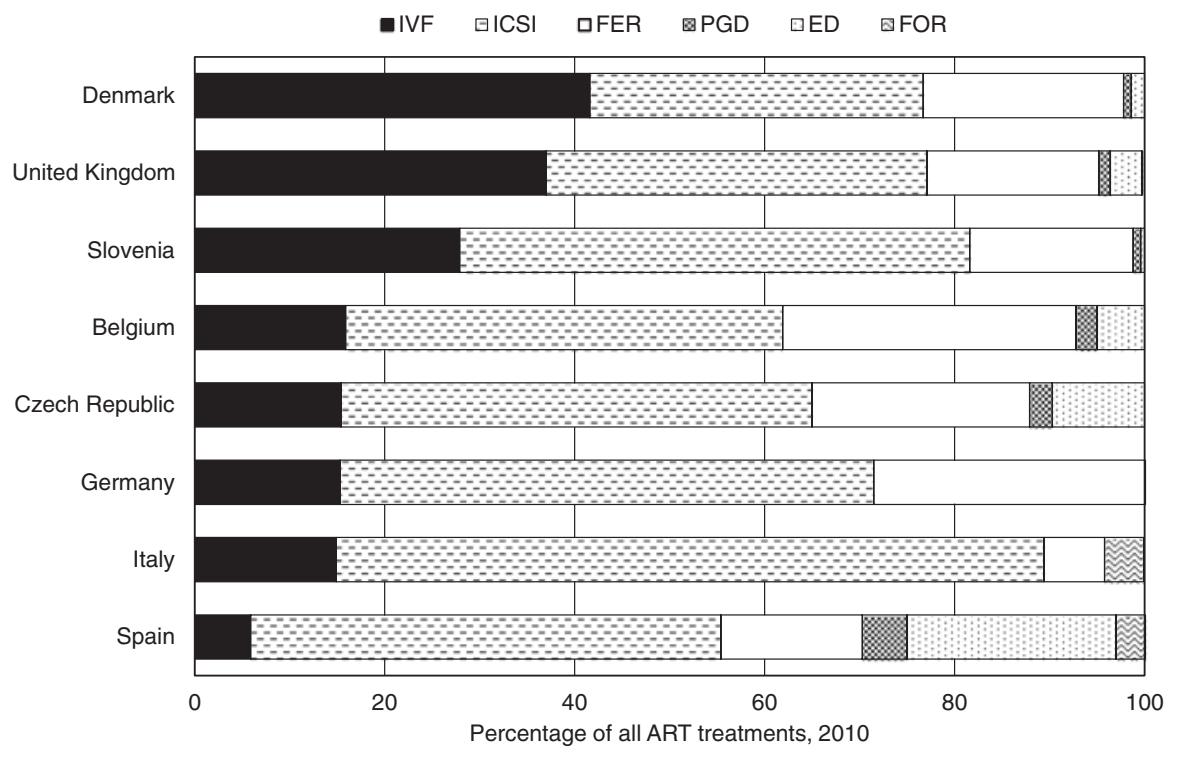

Fig. 14.2 ART treatments in selected countries, 2010 (Notes: $I V F$ in vitro fertilization (cycles), ICSI intracytoplasmic sperm injection (cycles), FER frozen embryo replacement (thawings), PGD preimplantation genetic diagnosis (cycles), ED egg donation (donations), FOR: frozen oocyte replacement (thawings). In vitro maturation (aspirations, $0.0-0.1 \%$ per country) not displayed. Source: Kupka et al. (2014))

these differences are still lacking (Nyboe Andersen et al. 2008). It is, however, clear that IVF and ICSI together make up the bulk of treatments in all countries.

The third-most popular form of ART treatment is frozen embryo replacement, making up between 6\% (Italy) and 31\% (Belgium) of ART treatments. The low uptake of FER in Italy is attributable to a national law that prohibited embryo cryopreservation (except under exceptional circumstances) from 2004 to 2009 (Benagiano and Gianaroli 2010). The relative popularity of FER in Germany is surprising, as German regulations regarding embryo freezing are fairly restrictive: i.e., the non-emergency freezing of embryos is banned, and the freezing of fertilized eggs is allowed only in the earliest stages of development. Preimplantation genetic diagnosis (PGD), which has been practiced since the early 1990s (Simpson 2010), is likely the ethically most controversial form of ART. PGD has clear benefits, as it can help parents avoid passing on inheritable disorders to their children, and it is generally considered to be safe and to have a low rate of errors (Ory et al. 2014). However, fears about the creation of "designer babies" and moral concerns about the use of PGD for non-medical purposes (such as sex selection) are often expressed in public discussions about ART. The data show that very few ART procedures involve PGD: the share of all ART treatments in a country that involve PGD ranges from no reported cases (in Germany and Italy) to $4.7 \%$ of cases (in Spain). The share is around $1 \%$ in Denmark, Slovenia, and the United Kingdom; and is around $2 \%$ in Belgium and the Czech Republic. Given the controversy surrounding PGD, 
it is interesting to note that the procedure is generally allowed in all of the countries listed in Fig. 14.2 (Ory et al. 2014); however, Denmark and Slovenia restrict its use to screening for specific hereditary disorders.

Egg donation is also a technique that is not practiced in all countries, as can be seen in Fig. 14.2. Germany and Italy report no cases, and in Slovenia and Denmark egg donation makes up less than $2 \%$ of ART procedures. In the United Kingdom and Belgium, the shares are slightly higher (3.3 and 5\%, respectively). In the Czech Republic and Spain a significant share (9.7 and 22\%) of ART treatments involve egg donation. As we will discuss in more detail below, it is important to note that these differences between countries are attributable in part to cross-border reproductive care. Couples and single women who are unable to obtain the desired treatment in their home country are sometimes willing to travel abroad to obtain that treatment in another country. Frozen oocyte replacement (FOR), which builds on fertilizing thawed oocytes, is a relatively rare form of ART: FOR treatments are reported only in the United Kingdom, Spain, and Italy $(0.1,3.1$, and $4.1 \%$, respectively). One reason for the relative popularity of FOR in Italy is that the cryopreserving of embryos was banned, which created incentives to further develop and refine technologies for cryopreserving oocytes.

\subsection{Regulation of Assisted Reproductive Technology in Europe}

Europe is the only continent where the legal regulation of ART is widespread. Other major countries where ART is used, such as India, Japan, and the U.S., largely rely on voluntary guidelines. While ART regulation is sometimes portrayed as a novel phenomenon, there is a long history of government interference in the reproductive realm. For example, countries have long had laws pertaining to marriage and divorce, contraception, births out of wedlock, adoption, and abortion (Spar 2005).

There are three major ways of regulating the practice of and the access to ART. First, ART can be regulated via guidelines, or sets of rules that practitioners are expected to follow voluntarily. These guidelines are generally issued by professional organizations, such as associations of obstetricians and gynaecologists. Second, as an alternative or a supplement to these guidelines, ART is also often subject to governmental legislation. Thus, rules for using ART are codified in the law, and penalties for the violation of these rules are imposed. A third route that regulates access to ART is insurance coverage: given the high cost of infertility treatments, the level of coverage can be seen as an indirect regulation of access to ART. However, because infertility is now seen as a condition leading to disability (WHO and World Bank 2011), infertile individuals should have a right to treatment.

The International Federation of Fertility Societies (IFFS) provides information on ART guidelines, regulations, and insurance coverage in their triennial 
"Surveillance Reports," which have been published since 1999 (Jones and Cohen 1999). The data in these reports are based on surveys of experts from national fertility societies. The IFFS data are organized into relatively broad categories, and are sometimes incomplete or inconsistent. Nonetheless, these reports provide a useful overview of the differences in ART governance across Europe. In the following, we present data from the most recent IFFS Surveillance Report (Ory et al. 2014), which refers to the year 2013. We include all of the European countries featured in the report, plus a number of contrasting non-European cases.

The left column of Table 14.1 reveals that in all European countries, ART is regulated under the law. In about half of the countries, governmental regulation is supplemented by voluntary guidelines. By contrast, for two of the three nonEuropean cases listed at the bottom of the Table (India and Japan), ART is fully governed by voluntary guidelines. While the distinction between legislation and guidelines does not reveal the scope and extent of the actual regulation, it roughly illustrates how important ART is to the respective government. The second column shows that ART legislation is a salient issue for governments, as half of the countries have introduced new ART legislation in the relatively short period of 4 years.

When it comes to the financing of ART treatments, virtually all European countries offer some assistance. Only Belarus, Ireland, and Switzerland do not provide their citizens with any form of coverage. Whereas most countries provide coverage via national health plans, some mandate that private insurers provide coverage. Six countries-Denmark, France, Hungary, Russia, Slovenia, and Spain-offer complete coverage through national health plans. A comparison with the results from Fig. 14.1 reveals that Denmark, Slovenia, and Spain are among the countries with particularly high ART utilization rates. In the countries where partial coverage is provided, the extent of the coverage varies considerably. For example, two-thirds of the costs are covered by the national health system in Austria, but only $40 \%$ of the costs are covered in Finland. Furthermore, the level of insurance coverage usually depends on patient characteristics. In Spain, for example, coverage is only available for women up to age 40. Slovenia covers six cycles for the first child and four cycles after a first live birth, but only for women up to age 42. In some parts of the United Kingdom, women who are obese are being denied coverage. In the U.S., there is substantial heterogeneity in coverage across the states, with a few states providing rather generous coverage, and the vast majority providing no coverage.

Couple and sexuality requirements represent a socially relevant aspect of ART policies, as they govern access to ART treatments over and above the financial restrictions that infertile couples and individuals face. Table 14.2 lists the couple and sexuality requirements, as reported by Ory et al. (2014) for all European countries and India, Japan, and the U.S. It should be noted that these requirements can stem from both legislation and guidelines. The first column of Table 14.2 reveals that marriage is a requirement for ART treatment in most countries. Only six out of 22 European countries in Table 14.2 report that marriage is not a requirement for ART access. However, apart from Turkey (and Japan), all of the European countries listed also provide treatment to couples who live in a stable relationship. Ory et al. (2014) acknowledged that "stable relationship" is a poorly defined concept open to 
14 Assisted Reproductive Technology in Europe: Usage and Regulation...

Table 14.1 Types of ART regulation in Europe, India, Japan, and the U.S., 2013

\begin{tabular}{|c|c|c|c|c|}
\hline Country & $\begin{array}{l}\text { Type of ART } \\
\text { governance }\end{array}$ & $\begin{array}{l}\text { New ART } \\
\text { legislation since } \\
2009\end{array}$ & Type of coverage & $\begin{array}{l}\text { Extent of } \\
\text { coverage }\end{array}$ \\
\hline Austria & $\begin{array}{l}\text { Legislation and } \\
\text { guidelines }\end{array}$ & No & National health plan & Partial \\
\hline Belarus & $\begin{array}{l}\text { Legislation and } \\
\text { guidelines }\end{array}$ & No & No coverage & None \\
\hline Belgium & Legislation only & Yes & $\begin{array}{l}\text { National health plan } \\
\text { and private } \\
\text { insurance }\end{array}$ & Partial \\
\hline Bulgaria & Legislation only & Yes & National health plan & Partial \\
\hline Croatia & Legislation only & Yes & $\begin{array}{l}\text { National health plan } \\
\text { and private } \\
\text { insurance }\end{array}$ & Partial \\
\hline $\begin{array}{l}\text { Czech } \\
\text { Republic }\end{array}$ & Legislation only & Yes & National health plan & Partial \\
\hline Denmark & Legislation only & Yes & National health plan & Complete \\
\hline Finland & Legislation only & No & National health plan & Partial \\
\hline France & $\begin{array}{l}\text { Legislation and } \\
\text { guidelines }\end{array}$ & Yes & National health plan & Complete \\
\hline Greece & Legislation only & No & National health plan & Partial \\
\hline Hungary & Legislation only & No & National health plan & Complete \\
\hline Iceland & Legislation only & No & National health plan & Partial \\
\hline Ireland & $\begin{array}{l}\text { Legislation and } \\
\text { guidelines }\end{array}$ & No & No coverage & None \\
\hline Italy & $\begin{array}{l}\text { Legislation and } \\
\text { guidelines }\end{array}$ & Yes & National health plan & Partial \\
\hline Latvia & $\begin{array}{l}\text { Legislation and } \\
\text { guidelines }\end{array}$ & Yes & National health plan & Partial \\
\hline Norway & $\begin{array}{l}\text { Legislation and } \\
\text { guidelines }\end{array}$ & No & National health plan & Partial \\
\hline Portugal & Legislation only & Yes & National health plan & Partial \\
\hline Russia & $\begin{array}{l}\text { Legislation and } \\
\text { guidelines }\end{array}$ & Yes & National health plan & Complete \\
\hline Slovenia & Legislation only & No & National health plan & Complete \\
\hline Spain & $\begin{array}{l}\text { Legislation and } \\
\text { guidelines }\end{array}$ & No & $\begin{array}{l}\text { National health plan } \\
\text { and private } \\
\text { insurance }\end{array}$ & Complete \\
\hline Sweden & $\begin{array}{l}\text { Legislation and } \\
\text { guidelines }\end{array}$ & No & National health plan & Partial \\
\hline Switzerland & $\begin{array}{l}\text { Legislation and } \\
\text { guidelines }\end{array}$ & No & No coverage & None \\
\hline Turkey & $\begin{array}{l}\text { Legislation and } \\
\text { guidelines }\end{array}$ & Yes & National health plan & Partial \\
\hline $\begin{array}{l}\text { United } \\
\text { Kingdom }\end{array}$ & $\begin{array}{l}\text { Legislation and } \\
\text { guidelines }\end{array}$ & Yes & Private insurance & Partial \\
\hline
\end{tabular}


Table 14.1 (continued)

\begin{tabular}{l|l|l|l|l}
\hline Country & $\begin{array}{l}\text { Type of ART } \\
\text { governance }\end{array}$ & $\begin{array}{l}\text { New ART } \\
\text { legislation since } \\
2009\end{array}$ & Type of coverage & $\begin{array}{l}\text { Extent of } \\
\text { coverage }\end{array}$ \\
\hline India & Guidelines only & No & No coverage & None \\
\hline Japan & Guidelines only & No & National health plan & Partial \\
\hline United States & $\begin{array}{l}\text { Legislation and } \\
\text { guidelines }\end{array}$ & No & Private insurance & Partial \\
\hline
\end{tabular}

Source: Ory et al. (2014)

Table 14.2 Couple and sexuality requirements for ART in Europe, India, Japan, and the U.S., 2013

\begin{tabular}{|c|c|c|c|c|}
\hline & $\begin{array}{l}\text { Marriage } \\
\text { required }\end{array}$ & $\begin{array}{l}\text { Stable relationship } \\
\text { permitted }\end{array}$ & $\begin{array}{l}\text { Singles } \\
\text { permitted }\end{array}$ & $\begin{array}{l}\text { Lesbians } \\
\text { permitted }\end{array}$ \\
\hline Austria & Yes & Yes & No & No \\
\hline Belgium & Yes & Yes & Yes & Yes \\
\hline Bulgaria & Yes & Yes & Yes & Yes \\
\hline Croatia & Yes & Yes & No & No \\
\hline Czech Republic & Yes & Yes & No & No \\
\hline Denmark & Yes & Yes & Yes & Yes \\
\hline Finland & No & Yes & Yes & Yes \\
\hline France & No & Yes & No & No \\
\hline Greece & No & Yes & Yes & No \\
\hline Hungary & Yes & Yes & Yes & No \\
\hline Ireland & No & Yes & No & No \\
\hline Italy & Yes & Yes & No & No \\
\hline Latvia & Yes & Yes & Yes & Yes \\
\hline Russia & Yes & Yes & Yes & No \\
\hline Slovenia & No & Yes & No & No \\
\hline Spain & Yes & Yes & Yes & Yes \\
\hline Sweden & Yes & Yes & No & No \\
\hline Switzerland & No & Yes & No & No \\
\hline Turkey & Yes & No & No & No \\
\hline United Kingdom & No & Yes & Yes & Yes \\
\hline India & Yes & Yes & Yes & No \\
\hline Japan & Yes & No & No & No \\
\hline United States & No & Yes & Yes & Yes \\
\hline
\end{tabular}

Source: Ory et al. (2014)

interpretation, yet it is widely embraced across countries. Countries are somewhat more restrictive in their rules regarding unpartnered women who want to undergo ART treatment. Only 10 of the 22 European countries, along with India and the U.S., permit singles to utilize ART services. Moreover, only seven European countries and the U.S. allow lesbian women to have access to ART. 
To better illustrate how European countries vary in their approach to regulating forms of ART, we examine the particularly controversial ART variant of surrogacy. There are several forms of surrogacy (see the notes below Table 14.3). The most prominent form is a traditional variant that uses the surrogate mother's egg. By contrast, in gestational surrogacy, the egg is provided by the intended mother or a donor, fertilized via IVF, and then transferred to the surrogate mother's womb.

The first central difference between countries lies in whether they prohibit (Table 14.3, column 1) or heavily regulate surrogacy (Table 14.3, column 3). Surrogacy is prohibited in many countries, such as France, Germany, Italy, Spain, and Portugal. Surrogate motherhood is explicitly allowed in Belgium, Belarus, Denmark, Greece, Ireland, the Russian Federation, Ukraine, and the United Kingdom. A second difference refers to compensation of the surrogate mother. When surrogacy is permitted, in some countries the prospective parents are not allowed to pay the surrogate mother beyond covering her "altruistic costs." Conversely, commercial surrogacy is legal in certain U.S. states, as well as in India, Ukraine, and the Russian Federation. In countries where surrogacy is prohibited, stakeholders have produced evidence that prospective parents may travel to other countries that allow commercial surrogacy. ${ }^{3}$ A third difference between countries relates to access to surrogacy. Since some countries require that both partners provide gametes when surrogates are used, singles are generally unable to have a child via surrogacy in these countries.

Finally, due to the frequent cross-border nature of surrogacy, highly contentious ethical and legal debates have arisen about the citizenship and parental rights of surrogate and adoptive parents. The media have recently reported numerous cases of babies who have been left without citizenship or parents. A famous case that demonstrates the legal problems that can arise is that of twins who were born to a gay male British couple, of whom one was the biological father, with the help of an anonymous egg donor and a Ukrainian surrogate mother (Henderson 2008). Because of conflicts between British and Ukrainian laws, the British father was not treated as a parent of the twins, and his children were not allowed to enter the United Kingdom. Conversely, the Ukrainian surrogate mother had waived all rights to custody of her biological offspring in a surrogacy agreement, which was, however, only recognized under Ukrainian law, and not under British law. In the end, the British couple were able to gain custody of the twins following a decision in a British court of law. Similar cases have been reported in Germany: for example, babies who were born outside of the country using surrogacy have been denied citizenship, even though the German parents were named on the birth certificate (The Local 2011). Concerns have been raised about the "Baby Gammy" case, in which a child with Down's syndrome who was born to a Thai surrogate mother was abandoned by the intended Australian parents. The child was recently granted Australian citizenship, and remains under the care of the Thai surrogate mother (Farrell 2015). The legal mechanisms for granting parenthood status remain unclear and differ depending on where the surrogate mother is located, or on a court's opinion regarding the best interests

\footnotetext{
${ }^{3}$ See, e.g., Surrogacy UK, http://www.surrogacyuk.org/
} 
Table 14.3 Overview of legal approaches to surrogacy, Europe and selected other countries, 2013

\begin{tabular}{|c|c|c|c|c|}
\hline & $\begin{array}{l}\text { General } \\
\text { prohibition }\end{array}$ & $\begin{array}{l}\text { Commercial } \\
\text { surrogacy allowed } \\
\text { or prohibited? }\end{array}$ & $\begin{array}{l}\text { Special law on } \\
\text { surrogacy? }\end{array}$ & $\begin{array}{l}\text { Adoption rules or } \\
\text { recognition of } \\
\text { citizenship of } \\
\text { children from } \\
\text { cross-border } \\
\text { surrogacy }\end{array}$ \\
\hline Austria & $\begin{array}{l}\text { Egg donation } \\
\text { prohibited; } \\
\text { gestational } \\
\text { surrogacy } \\
\text { allowed }\end{array}$ & $\begin{array}{l}\text { No specific } \\
\text { prohibition for } \\
\text { traditional } \\
\text { surrogacy }\end{array}$ & $\begin{array}{l}\text { No for } \\
\text { traditional } \\
\text { surrogacy }\end{array}$ & $\begin{array}{l}\text { No recognition of } \\
\text { child's citizenship }\end{array}$ \\
\hline Belarus & Allowed & Unknown & Unknown & Unknown \\
\hline Belgium & Allowed $^{\mathrm{b}}$ & $\begin{array}{l}\text { Prohibited on } \\
\text { public policy } \\
\text { grounds }\end{array}$ & $\begin{array}{l}\text { No for altruistic } \\
\text { surrogacy }\end{array}$ & $\begin{array}{l}\text { Adoption required } \\
\text { to transfer legal } \\
\text { parenthood }\end{array}$ \\
\hline Bulgaria & Prohibited & $\mathrm{n} / \mathrm{a}$ & $\begin{array}{l}\text { No, but draft } \\
\text { legislation under } \\
\text { consideration }\end{array}$ & $\mathrm{n} / \mathrm{a}$ \\
\hline Cyprus & Allowed & $\begin{array}{l}\text { Allowed/no } \\
\text { prohibition }\end{array}$ & Yes & $\begin{array}{l}\text { Surrogate mother } \\
\text { and biological } \\
\text { father listed on } \\
\text { birth certificate }\end{array}$ \\
\hline $\begin{array}{l}\text { Czech } \\
\text { Republic }\end{array}$ & Allowed & $\begin{array}{l}\text { Allowed/no } \\
\text { prohibition }\end{array}$ & Yes & Unknown \\
\hline Denmark & Allowed $^{\mathrm{b}}$ & Prohibited & $\begin{array}{l}\text { No for altruistic } \\
\text { surrogacy }\end{array}$ & $\begin{array}{l}\text { Adoption required } \\
\text { to transfer legal } \\
\text { parenthood }\end{array}$ \\
\hline Estonia & Allowed & $\begin{array}{l}\text { Allowed/no } \\
\text { prohibition }\end{array}$ & Yes & Unknown \\
\hline Finland & $\begin{array}{l}\text { Prohibited for } \\
\text { IVF }\end{array}$ & $\begin{array}{l}\text { No specific } \\
\text { prohibition for } \\
\text { traditional } \\
\text { surrogacy }\end{array}$ & $\begin{array}{l}\text { No for } \\
\text { traditional } \\
\text { surrogacy }\end{array}$ & Unknown \\
\hline France & Prohibited & $\mathrm{n} / \mathrm{a}$ & $\mathrm{n} / \mathrm{a}$ & Unknown \\
\hline Germany & Prohibited & $\mathrm{n} / \mathrm{a}$ & $\mathrm{n} / \mathrm{a}$ & $\begin{array}{l}\text { No recognition of } \\
\text { child's citizenship }\end{array}$ \\
\hline Greece & Allowed & $\begin{array}{l}\text { Allowed/no } \\
\text { prohibition }\end{array}$ & $\begin{array}{l}\text { Yes: altruistic } \\
\text { gestational } \\
\text { surrogacy } \\
\text { subject to } \\
\text { restrictions }\end{array}$ & $\begin{array}{l}\text { Surrogate mother } \\
\text { and biological } \\
\text { father listed on } \\
\text { birth certificate }\end{array}$ \\
\hline Hungary & Allowed & Prohibited & $\begin{array}{l}\text { No for altruistic } \\
\text { surrogacy }\end{array}$ & \\
\hline
\end{tabular}


Table 14.3 (continued)

\begin{tabular}{|c|c|c|c|c|}
\hline & $\begin{array}{l}\text { General } \\
\text { prohibition }\end{array}$ & $\begin{array}{l}\text { Commercial } \\
\text { surrogacy allowed } \\
\text { or prohibited? }\end{array}$ & $\begin{array}{l}\text { Special law on } \\
\text { surrogacy? }\end{array}$ & $\begin{array}{l}\text { Adoption rules or } \\
\text { recognition of } \\
\text { citizenship of } \\
\text { children from } \\
\text { cross-border } \\
\text { surrogacy }\end{array}$ \\
\hline Ireland & Allowed $^{\mathrm{b}}$ & Prohibited & $\begin{array}{l}\text { No for altruistic } \\
\text { surrogacy but } \\
\text { formal } \\
\text { guidelines for } \\
\text { cross-border } \\
\text { surrogacy } \\
\text { agreements }\end{array}$ & $\begin{array}{l}\text { Adoption required } \\
\text { to transfer parents; } \\
\text { genetic intended } \\
\text { parents' names as } \\
\text { legal parents on } \\
\text { birth registry }\end{array}$ \\
\hline Italy & Prohibited & $\mathrm{n} / \mathrm{a}$ & $\mathrm{n} / \mathrm{a} /$ & Unknown \\
\hline Latvia & Allowed & Prohibited & $\begin{array}{l}\text { No for altruistic } \\
\text { surrogacy }\end{array}$ & Unknown \\
\hline Lithuania & Allowed & $\begin{array}{l}\text { Allowed/no } \\
\text { prohibition }\end{array}$ & Yes & Unknown \\
\hline Luxembourg & Allowed & $\begin{array}{l}\text { Allowed/no } \\
\text { prohibition }\end{array}$ & Yes & Unknown \\
\hline Malta & Prohibited & $\mathrm{n} / \mathrm{a}$ & $\mathrm{n} / \mathrm{a}$ & Unknown \\
\hline Norway & Prohibited & $\mathrm{n} / \mathrm{a}$ & No & \\
\hline Netherlands & Allowed ${ }^{b}$ & Prohibited & $\begin{array}{l}\text { Yes altruistic } \\
\text { gestational } \\
\text { surrogacy } \\
\text { required by law } \\
\text { to abide by } \\
\text { professional } \\
\text { guidelines }\end{array}$ & $\begin{array}{l}\text { No special law for } \\
\text { parenthood: } \\
\text { adoption required }\end{array}$ \\
\hline Poland & Allowed & $\begin{array}{l}\text { Allowed/no } \\
\text { prohibition }\end{array}$ & Yes & $\begin{array}{l}\text { Surrogate mother } \\
\text { and biological } \\
\text { father listed on } \\
\text { birth certificate }\end{array}$ \\
\hline Portugal & Prohibited & $\mathrm{n} / \mathrm{a}$ & $\mathrm{n} / \mathrm{a}$ & Unknown \\
\hline Russian Fed. & Allowed & $\begin{array}{l}\text { Allowed/no } \\
\text { prohibition }\end{array}$ & Unknown & Unknown \\
\hline Slovakia & Allowed & $\begin{array}{l}\text { Allowed/no } \\
\text { prohibition }\end{array}$ & Yes & Unknown \\
\hline Slovenia & Allowed & $\begin{array}{l}\text { Allowed/no } \\
\text { prohibition }\end{array}$ & Yes & Unknown \\
\hline Spain & Prohibited & $\mathrm{n} / \mathrm{a}$ & $\mathrm{n} / \mathrm{a}$ & Unknown \\
\hline
\end{tabular}


Table 14.3 (continued)

\begin{tabular}{|c|c|c|c|c|}
\hline & $\begin{array}{l}\text { General } \\
\text { prohibition }\end{array}$ & $\begin{array}{l}\text { Commercial } \\
\text { surrogacy allowed } \\
\text { or prohibited? }\end{array}$ & $\begin{array}{l}\text { Special law on } \\
\text { surrogacy? }\end{array}$ & $\begin{array}{l}\text { Adoption rules or } \\
\text { recognition of } \\
\text { citizenship of } \\
\text { children from } \\
\text { cross-border } \\
\text { surrogacy }\end{array}$ \\
\hline Sweden & $\begin{array}{l}\text { Prohibited for } \\
\text { fertility clinics } \\
\text { to make } \\
\text { surrogacy } \\
\text { arrangements }\end{array}$ & Prohibited & $\begin{array}{l}\text { No law for } \\
\text { privately } \\
\text { arranged } \\
\text { surrogacy; } \\
\text { Swedish Council } \\
\text { Medical Ethics } \\
\text { recently } \\
\text { recommended } \\
\text { altruistic } \\
\text { surrogacy } \\
\text { should be } \\
\text { permitted }\end{array}$ & $\begin{array}{l}\text { Adoption required } \\
\text { to transfer } \\
\text { parenthood }\end{array}$ \\
\hline Switzerland & Prohibited & $\mathrm{n} / \mathrm{a}$ & $\mathrm{n} / \mathrm{a}$ & $\begin{array}{l}\text { No recognition of } \\
\text { child's citizenship }\end{array}$ \\
\hline Turkey & Prohibited & $\mathrm{n} / \mathrm{a}$ & $\mathrm{n} / \mathrm{a}$ & Unknown \\
\hline Ukraine & Allowed & $\begin{array}{l}\text { Allowed/no } \\
\text { prohibition }\end{array}$ & Unknown & $\begin{array}{l}\text { Intended parents' } \\
\text { names on birth } \\
\text { certificate }\end{array}$ \\
\hline $\begin{array}{l}\text { United } \\
\text { Kingdom }\end{array}$ & Allowed $^{\mathrm{b}}$ & Prohibited & $\begin{array}{l}\text { No for altruistic } \\
\text { surrogacy }\end{array}$ & $\begin{array}{l}\text { Parenthood only } \\
\text { transferred in } \\
\text { certain } \\
\text { circumstances }\end{array}$ \\
\hline India & Allowed & $\begin{array}{l}\text { Allowed/no } \\
\text { prohibition }\end{array}$ & Yes & $\begin{array}{l}\text { Parents' names on } \\
\text { birth certificate, } \\
\text { Indian surrogates } \\
\text { cannot be named } \\
\text { as mother }\end{array}$ \\
\hline Japan & Prohibited & $\mathrm{n} / \mathrm{a}$ & $\mathrm{n} / \mathrm{a}$ & Unknown \\
\hline Canada & Allowed ${ }^{\mathrm{b}}$ & Prohibited & Unknown & Unknown \\
\hline United States & Allowed $^{\mathrm{a}}$ & $\begin{array}{l}\text { Allowed/certain } \\
\text { prohibitions }\end{array}$ & Yes & $\begin{array}{l}\text { Parents' names on } \\
\text { birth certificate }\end{array}$ \\
\hline
\end{tabular}

Notes: In traditional surrogacy, the surrogate mother is the genetic mother, as one of her eggs is inseminated using the sperm of the intended father or donated sperm (either IVF or insemination). In altruistic surrogacy, the surrogate mother is paid nothing or only enough to cover her expenses. In commercial surrogacy, the surrogate mother is paid a fee that may exceed her expenses Source: Brunet et al. (2013), Ory et al. (2014), Families Thru Surrogacy (2015). When expert interviews from IFFS data from Ory et al. (2014) differed from legal and clinical survey data reported by Brunet et al. (2013), the latter data were adopted over the expert interviews ${ }^{a}$ Allowed in California, Maryland, Massachusetts, Ohio, Pennsylvania, South Carolina, Alabama, Arkansas, Connecticut, Illinois, Iowa, Nevada, North Dakota, Oregon, Tennessee, Texas, Utah, and West Virginia

${ }^{\mathrm{b}}$ Allowed only for non-commercial surrogacy (i.e., the mother is not paid or is paid only enough to cover her expenses) 
of the child. It appears that when many ART laws were initially written or amended, surrogacy was often excluded or barely acknowledged.

\subsection{Cross-Border Reproductive Care in Europe}

As we touched upon in our discussion on surrogate motherhood, the variation in regulations in Europe has given rise to the phenomenon of cross-border reproductive care (Shenfield et al. 2010; Nygren et al. 2010). Cross-border reproductive care refers to couples or individuals seeking assisted reproduction treatments in a country other than their country of permanent residence. ${ }^{4}$ Although practitioners, patients, and policy-makers appear to be aware of this phenomenon, there is little empirical research on the actual extent of cross-border reproductive care. The review article by Hudson et al. (2011) tellingly reported that the number of commentaries on the topic greatly exceeds the number of empirical studies.

So far, researchers have been unable to generate reliable estimates of the incidence of cross-border reproductive care. The most ambitious attempt to conduct a global survey of this form of care was by Nygren et al. (2010), who collected information from experts in 23 countries. Virtually all of the reports were based on estimates by informants rather than empirical data, and the authors concluded that their efforts yielded "little, if any, solid data" on cross-border reproductive care. The estimates of Nygren et al. suggest that most cross-border reproductive care in Europe involves traveling to other European countries, not to other continents.

The largest study of patients undergoing cross-border reproductive care in Europe was conducted in 2008/09 by Shenfield et al. (2010). They surveyed all women from other countries who were undergoing treatment in 44 fertility clinics in Belgium, the Czech Republic, Denmark, Switzerland, Slovenia, and Spain. The main countries of origin of the women seeking care were Italy (32\%), Germany $(15 \%)$, the Netherlands $(12 \%)$, and France $(9 \%)$. Geographic and cultural proximity is a driving factor in the choice of treatment country: the majority of Italians traveled to Spain and Switzerland, most of the Germans traveled to the Czech Republic, the majority of the Dutch and French women went to Belgium, and most of the Norwegian and Swedish women traveled to Denmark. Shenfield and colleagues suggest that a conservative estimate of cross-border reproductive care (i.e., crossing country borders in order to undergo ART) in 2008/2009 would be one of 11,000-14,000 patients and 24,000-30,000 treatment cycles in the six countries alone. When confronted with the number of ART cycles (2008: 532,000; 2009: 537,000 ) counted in all of Europe at that time (Ferraretti et al. 2012; Ferraretti et al. 2013), this is a small, yet substantial share of patients and cycles.

\footnotetext{
${ }^{4}$ This phenomenon is also sometimes referred to as "reproductive tourism" or "reproductive exile" (Pennings 2005), but given the charged nature of both terms, we follow Shenfield et al. (2010) in their use of the more descriptive and neutral term "cross-border reproductive care."
} 
The reasons for seeking cross-border reproductive care are diverse, with patients reporting a combination of factors (Culley et al. 2011). The main reasons cited were legal restrictions, difficulties in accessing ART treatments (e.g., long waiting lists), the expectation of better quality treatment in the destination country, and the failure of previous treatments in the patient's country of origin. A number of studies have described the legal reasons why ART patients seek treatment in other countries. For example, egg donation is a form of assisted reproduction that is banned in some European countries, including Germany. Thus, some German couples travel to the Czech Republic or Spain for egg donation (Bergmann 2011). In France, single women and lesbian couples lack access to donor sperm (see Table 14.2). Thus, these women sometimes travel to Belgium to seek treatment (van Hoof et al. 2015; Rozée Gomez and de La Rochebrochard 2013). Certain countries, like the United Kingdom, have long waiting lists for donor gametes, and patients who wish to avoid lengthy waiting periods seek treatment in countries where donor gametes are more readily available (Culley et al. 2011). These long waiting periods have arisen for a number of reasons. For example, some countries (e.g., Finland, Sweden, and the United Kingdom) have banned anonymous gamete donation, which tends to discourage donation. There is also considerable variation across countries in the amounts donors are paid. Patients from countries such as Italy hope to receive better quality treatments abroad (Zanini 2011; Shenfield et al. 2010), while other patients go abroad because the previous treatments they received in their country of residence failed (Shenfield et al. 2010; Culley et al. 2011). In their comparative study of patients seeking treatment abroad, Shenfield and colleagues (2010) found evidence that supports the assumption that differences in regulations are important drivers of cross-border fertility care. Between 57 and $80 \%$ of patients from Italy, Germany, Norway, France, and Sweden cited legal restrictions as one of the reasons why they were seeking fertility treatment abroad. By contrast, only $32 \%$ of patients from the Netherlands and $9 \%$ of patients from the United Kingdom cited legal barriers. However, $53 \%$ of patients from the Netherlands reported that they went abroad to obtain better quality treatment (compared to an average of $43 \%$ across the six countries surveyed), while $34 \%$ of the patients from the United Kingdom said they went abroad because of access difficulties (compared to an average of $7 \%$ across the six countries surveyed).

While the extent to which European patients cross borders to obtain reproductive care appears to be limited, cross-border care has far-reaching consequences and implications for ART regulation, access, and treatment success rates. Because it is relatively easy and inexpensive for Europeans to travel across borders to obtain care, the value of legal restrictions on ART is largely symbolic (van Beers 2015). Furthermore, as patients can easily circumvent national regulations by seeking treatment abroad, patient groups and other national stakeholders may have reduced incentives to make their interests known in the policy-making process. This lack of pressure allows policy-makers to impose more onerous restrictions than they would have if they had been facing more resistance from stakeholders (Storrow 2010). Furthermore, cross-border reproductive care has implications for equity of access to ART. Rozée Gomez and de la Rochebrochard (2013) have reported that lower 
income French patients seek fertility treatment in Greece for financial reasons. This might in turn affect access to ART within Greece, as local patients might be "priced out" of the market for ART services.

\subsection{Discussion}

This study has shown that there is marked variation in ART usage levels across Europe, and that the highest levels are not just in affluent countries such as Denmark and Belgium, but also in Slovenia, the Czech Republic, Estonia, and Serbia. The reasons for this variation include affordability, reimbursement levels, and the social and cultural norms surrounding childbearing. A striking shift has been the move away from IVF as the dominant form of ART, and toward ICSI, a method used primarily to treat male infertility. We also show that the mix of treatments used varies across countries.

Currently, all of the European countries have laws on ART, and virtually all (with the exception of Belarus, Ireland, and Switzerland) provide some sort of financial assistance for treatments. The countries where the cost of treatments is completely covered by national health plans — such as Denmark, Slovenia, and Spain — have the highest ART utilization rates. Coverage also differs by patient characteristics, such as the age of the prospective mother and how many children she already has. In many countries, patients who seek ART treatments must be legally married or in a stable partnership. Currently only half of European countries permit single women to have ART treatments, and even fewer countries grant access to lesbian women.

We also looked at the increasingly relevant issue of surrogacy and cross-border reproductive care. Surrogacy is strictly prohibited in many countries, and where it is allowed, there are often restrictions on commercial surrogacy. Due to the frequent cross-border nature of surrogacy, there is considerable confusion about which laws apply when determining the citizenship of the child and the parental rights of the surrogate and the adoptive parents. The growth in cross-border reproductive care means that restrictive national regulations can be easily circumvented, but it raises questions about equity of access. Cross-border reproductive care is a transnational phenomenon that forces social scientists and policy-makers to think beyond the confines of the nation-state (Mau and Verwiebe 2010; Wimmer and Glick Schiller 2002). Notwithstanding all of the problems related to patients crossing borders to achieve fertility treatment, it is important to acknowledge that women have been crossing borders in Europe for a long time to abort pregnancies, exploiting country differences in reproductive legislation.

Recently, there has been a rise in the uptake of techniques such as the "social freezing" of eggs, and it has even been suggested that ART could help countries raise their fertility levels. However, we would be reluctant to argue that it is an upcoming policy to reconcile career and family aspirations, such as measures that encourage flexible work schedules (Präg and Mills 2014) or improve access to public childcare (Mills et al. 2014). Because ART treatments tend to have low success 
rates at higher ages, they cannot be expected to reverse the "biological clock" (Präg et al. 2015; Wyndham et al. 2012).

This study also showed some strong limitations in what we are able to conclude, which is due to the lack of data about ART in Europe. In the future, researchers should first attempt to standardize the collection of data on ART treatments and their outcomes, as this would improve our knowledge of the individual antecedents and effects of ART. Second, researchers should develop national databases to collect quantitative information that can be linked across countries, as cross-border reproductive care needs to be properly registered. Third, we need these initiatives to not only monitor cross-border reproductive care in Europe, but also to support caregivers in providing help for patients both undergoing and returning from cross-border fertility care in these often legally diffuse situations.

Although Europe is currently the biggest market for ART in the world, it is important to note that the demand for ART is relatively low in Europe. Paradoxically, involuntary childlessness is most prevalent (and is perceived by infertile women as most pressing) in Africa, where fertility levels are the highest in the world. Given the increasing international recognition of the problem and the push for the low-cost provision of ART (Ombelet 2014), the "globalization of ART" has yet to be achieved (Inhorn and Patrizio 2015).

Acknowledgements The research leading to these results has received funding from the European Union's Seventh Framework Program (FP7 2007-2013) under grant agreement no. 320116 for the research project Families and Societies (familiesandsocieties.eu).

\section{Literature}

Adamson, G. D., Tabangin, M., Macaluso, M., \& de Mouzon, J. (2013). The number of babies born globally after treatment with the assisted reproductive technologies (ART). Fertility and Sterility, 100, S42.

Benagiano, G., \& Gianaroli, L. (2010). The Italian constitutional court modifies Italian legislation on assisted reproduction technology. Reproductive Biomedicine Online, 20, 398-402.

Bergmann, S. (2011). Reproductive agency and projects. Germans searching for egg donation in Spain and the Czech Republic. Reproductive Biomedicine Online, 23, 600-608.

Billari, F. C., Goisis, A., Liefbroer, A. C., Settersten, R. A., Aassve, A., Hagestad, G., et al. (2011). Social age deadlines for the childbearing of women and men. Human Reproduction Update, 26, 616-622.

Boulet, S. L., Mehta, A., Kissin, D. M., Warner, L., Kawwass, J. F., \& Jamieson, D. J. (2015). Trends in use of and reproductive outcomes associated with intracytoplasmic sperm injection. JAMA, 313, 255-263.

Brunet, L., Carruthers, J., Davaki, K., King, D., Marzo, C., \& McCandles, J. (2013). A comparative study on the regime of surrogacy in EU member states. Brussels: European Parliament.

Chambers, G. M., Hoang, V. P., Sullivan, E. A., Chapman, M. G., Ishihara, O., Zegers-Hochschild, F., et al. (2014). The impact of consumer affordability on access to assisted reproductive technologies and embryo transfer practices. Fertility and Sterility, 101, 191-198. e194.

Culley, L., Hudson, N., Rapport, F., Blyth, E., Norton, W., \& Pacey, A. A. (2011). Crossing borders for fertility treatment. Motivations, destinations, and outcomes of UK fertility travelers. Human Reproduction Update, 26, 2373-2381. 
Families Thru Surrogacy. (2015). Surrogacy by country: http://www.familiesthrusurrogacy.com/ surrogacy-by-country. Accessed 20 Aug 2015.

Farrell, P. (2015, January 19). Baby gammy, born into Thai surrogacy scandal, granted Australian citizenship. The Guardian. http://www.theguardian.com/australia-news/2015/jan/20/babygammy-born-into-thai-surrogacy-scandal-granted-australian-citizenship. Accessed 20 Aug 2015.

Ferraretti, A. P., Goossens, V., de Mouzon, J., Bhattacharya, S., Castilla, J. A., Korsak, V., et al. (2012). Assisted reproductive technology in Europe, 2008. Results generated from European registers by ESHRE. Human Reproduction Update, 27, 2571-2584.

Ferraretti, A. P., Goossens, V., Kupka, M., Bhattacharya, S., De Mouzon, J., Castilla, J. A., et al. (2013). Assisted reproductive technology in Europe, 2009. Results generated from European registers by ESHRE. Human Reproduction Update, 28, 2318-2331.

Greene, M. E., \& Biddlecom, A. E. (2000). Absent and problematic Men. Demographic accounts of male reproductive roles. Population and Development Review, 26, 81-115.

Hamilton, B. H., \& McManus, B. (2012). The effects of insurance mandates on choices and outcomes in infertility treatment markets. Health Economics, 21, 994-1016.

Henderson, M. (2008, December 12). British surrogacy ruling saves baby twins from Ukraine orphanage. The Times. http://www.thetimes.co.uk/tto/law/article2212834.ece. Accessed 20 Aug 2015.

Hudson, N., Culley, L., Blyth, E., Norton, W., Rapport, F., \& Pacey, A. (2011). Cross-border reproductive care. A review of the literature. Reproductive Biomedicine Online, 22, 673-685.

Inhorn, M. C., \& Patrizio, P. (2015). Infertility around the globe. New thinking on gender, reproductive technologies, and global movements in the 21st Century. Human Reproduction Update, $21,411-426$.

Jones, H. W., Jr., \& Cohen, J. (1999). IFFS Surveillance 1998. Fertility and Sterility, 71, S1-S34.

Kocourkova, J., Burcin, B., \& Kucera, T. (2014). Demographic relevancy of increased use of assisted reproduction in European countries. Reproductive Health, 11, 37.

Kohler, H.-P., Billari, F. C., \& Ortega, J. A. (2002). The emergence of lowest-low fertility in Europe during the 1990's. Population and Development Review, 28, 641-680.

Kupka, M. S., Ferraretti, A. P., De Mouzon, J., Erb, K., D'Hooghe, T., Castilla, J. A., et al. (2014). Assisted reproductive technology in Europe, 2010. Results generated from European registers by ESHRE. Human Reproduction Update, 29, 2099-2113.

Malizia, B. A., Hacker, M. R., \& Penzias, A. S. (2009). Cumulative live-birth rates after In Vitro fertilization. New England Journal of Medicine, 360, 236-243.

Mascarenhas, M. N., Flaxman, S. R., Boerma, T., Vanderpoel, S., \& Stevens, G. A. (2012). National, regional, and global trends in infertility prevalence since 1990. A systematic analysis of 277 health surveys. Plos Medicine, 9, e1001356.

Mau, S., \& Verwiebe, R. (2010). European societies. Mapping structure and change. Bristol: Policy.

Mertes, H., \& Pennings, G. (2011). Social egg freezing. For better, not for worse. Reproductive Biomedicine Online, 23, 824-829.

Mills, M., \& Präg, P. (2015). Norms, politics, and assisted reproductive technology (ART) policies. A cross-national comparative analysis. Paper presented at the annual meeting of the population association of America, San Diego.

Mills, M., Rindfuss, R. R., McDonald, P., \& te Velde, E. (2011). Why do people postpone parenthood? Reasons and social policy incentives. Human Reproduction Update, 17, 848-860.

Mills, M., Präg, P., Tsang, F., Begall, K., Derbyshire, J., Kohle, L., et al. (2014). Use of childcare services in the EU member states and progress towards the Barcelona targets. Brussels: European Commission DG Justice.

Nyboe Andersen, A., Carlsen, E., \& Loft, A. (2008). Trends in the use of intracytoplasmatic sperm injection. Marked variability between countries. Human Reproduction Update, 14, 593-604.

Nygren, K., Adamson, D., Zegers-Hochschild, F., \& de Mouzon, J. (2010). Cross-border fertility care. International committee monitoring assisted reproductive technologies global survey. 2006 data and estimates. Fertility and Sterility, 94, e4-e10. 
Ombelet, W. (2014). Is global access to infertility care realistic? The Walking Egg project. Reproductive Biomedicine Online, 28, 267-272.

Ory, S. J., Devroey, P., Banker, M., Brinsden, P., Buster, J., Fiadjoe, M., et al. (2014). IFFS surveillance 2013. Preface and conclusions. Fertility and Sterility, 101, 1582-1583.

Palermo, G. D., Joris, H., Devroey, P., \& Van Steirteghem, A. C. (1992). Pregnancies after intracytoplasmic injection of single spermatozoon into an oocyte. Lancet, 340, 17-18.

Pennings, G. (2005). Reproductive exile versus reproductive tourism. Human Reproduction Update, 20, 3571-3572.

Präg, P., \& Mills, M. (2014). Family-related working schedule flexibility across Europe. Brussels: European Commission DG Justice.

Präg, P., Mills, M., Tanturri, M. L., Monden, C., \& Pison, G. (2015). The demographic consequences of assisted reproductive technologies: Deliverable D4.6 of 'Families and Societies'.

Rozée Gomez, V., \& de La Rochebrochard, E. (2013). Cross-border reproductive care among French patients. Experiences in Greece, Spain, and Belgium. Human Reproduction Update, 28, 3103-3110.

Shenfield, F., de Mouzon, J., Pennings, G., Ferraretti, A. P., Nyboe Andersen, A., de Wert, G., et al. (2010). Cross-border reproductive care in six European countries. Human Reproduction Update, 25, 1361-1368.

Simpson, J. L. (2010). Preimplantation genetic diagnosis at 20 years. Prenatal Diagnosis, 30, 682-695.

Sobotka, T. (2010). Shifting parenthood to advanced reproductive ages. Trends, causes and consequences. In J. C. Tremmel (Ed.), A young generation under pressure? The financial situation and the "rush hour" of the cohorts 1970-1985 in a generational comparison (pp. 129-154). Berlin: Springer.

Spar, D. (2005). Reproductive tourism and the regulatory map. New England Journal of Medicine, $352,531-533$.

Steptoe, P. C., \& Edwards, R. G. (1978). Birth after the reimplatation of a human embryo. Lancet, $312,366$.

Storrow, R. F. (2010). The pluralism problem in cross-border reproductive care. Human Reproduction Update, 25, 2939-2943.

te Velde, E. R., \& Pearson, P. L. (2002). The variability of female reproductive ageing. Human Reproduction Update, 8, 141-154.

te Velde, E. R., Habbema, D., Leridon, H., \& Eijkemans, M. (2012). The effect of postponement of first motherhood on permanent involuntary childlessness and total fertility rate in six European countries since the 1970's. Human Reproduction Update, 27, 1179-1183.

The Local. (2011, April 28). Surrogate children have no right to German Passport, Court Rules. The Local. http://www.thelocal.de/20110428/34681. Accessed 20 Aug 2015.

Tran, M. (2014, October 15). Apple and Facebook offer to freeze eggs for female employees. The Guardian. http://www.theguardian.com/technology/2014/oct/15/apple-facebook-offer-freezeeggs-female-employees. Accessed 20 Aug 2015.

van Beers, B. C. (2015). Is Europe 'Giving in to Baby Markets?' Reproductive tourism in Europe and the gradual erosion of existing legal limits to reproductive markets. Medical Law Review, $23,103-134$.

van Hoof, W., Pennings, G., \& de Sutter, P. (2015). Cross-border reproductive care for law evasion. A qualitative study into the experiences and moral perspectives of French women who go to Belgium for treatment with donor sperm. Social Science and Medicine, 124, 391-397.

WHO, World Bank. (2011). World report on disability. Geneva: WHO.

Wimmer, A., \& Glick Schiller, N. (2002). Methodological nationalism and beyond. Nation-state building, migration, and the social sciences. Global Networks, 2, 301-334.

Wyndham, N., Marin Figueira, P. G., \& Patrizio, P. (2012). A persistent misperception: Assisted reproductive technology can reverse the 'aged biological clock.'. Fertility and Sterility, 97, $1044-1047$.

Zanini, G. (2011). Abandoned by the state, betrayed by the church. Italian experiences of crossborder reproductive care. Reproductive Biomedicine Online, 23, 565-572. 
Zegers-Hochschild, F., Adamson, G. D., de Mouzon, J., Ishihara, O., Mansour, R., Nygren, K. G., et al. (2009). International committee for monitoring assisted reproductive technology (ICMART) and the World Health Organization (WHO) revised glossary of ART terminology, 2009. Fertility and Sterility, 92, 1520-1524.

Zegers-Hochschild, F., Mansour, R., Ishihara, O., Adamson, G. D., de Mouzon, J., Nygren, K. G., et al. (2014). International committee for monitoring assisted reproductive technology. World report on assisted reproductive technology, 2005. Fertility and Sterility, 101, 366-378.

Open Access This chapter is distributed under the terms of the Creative Commons Attribution 4.0 International License (http://creativecommons.org/licenses/by/4.0/), which permits use, duplication, adaptation, distribution and reproduction in any medium or format, as long as you give appropriate credit to the original author(s) and the source, provide a link to the Creative Commons license and indicate if changes were made.

The images or other third party material in this chapter are included in the work's Creative Commons license, unless indicated otherwise in the credit line; if such material is not included in the work's Creative Commons license and the respective action is not permitted by statutory regulation, users will need to obtain permission from the license holder to duplicate, adapt or reproduce the material. 